\title{
SERO-EPIDEMIOLOGICAL STUDIES OF INFLUENZA IN VARNA REGION FOR THE PERIOD 1990-2004
}

\author{
Russev V., L. Ivanova, V. Lyoutzkanova \\ Department of Microbiology and Virology, Medical University "Prof. P. Stoyanov" - Varna
}

Reviewed by: Assoc. Prof. K. Bozhova

\section{SUMMARY}

With modern methods for studying antigenic structure and some biological properties of 10 of isolated strains influenza type A were examined their haemadsorption, haemagglutination, inhibitorsusceptible, eluent, pathogenic, toxic and immunogenic activity. The studies showed continuing active circulation of influenza type A viruses with formula $\mathrm{H}_{3} \mathrm{~N}_{2}$, antigenically similar to standard strains $\mathrm{A} / \mathrm{Washington} / \mathbf{1 5} / \mathbf{9 1}$, A/Beijing/32/92, A/Johanesburg/33/95, A/Uhan/359/95, A/Sidney/5/97 and A/Moscow/1/99 (H3N2), with the respective biological properties.

Key words: Influenza virus, antihaemaglutinine, titers of antibody, haemagglutination inhibition

It is known that infectious process is relationship between macro and microorganisms. The epidemiological process is a complex self-regulating system, influenced by social and nature factors of relation between heterogeneous populations of human and microorganisms. Based on this definition, when studying the specialties of epidemiological process of Influenza is necessary to pay attention especially to the changeability of Influenza virus, its way of distribution and the resistance of macro organism $(7,8,9)$.

The specific immunity of the population to Influenza virus has the leading role in forming and progress of the epidemiological process $(1,2,3)$.

The aim of this study is to determine the mean geometrical titers of antihaemaglutinine Abs to different strains of Influenza virus type A $(4,6)$.

\section{MATERIALS AND METHODS}

16000 single serum samples of healthy persons from different age-groups from Varna region were tested. Our studies were performed using Haemagglutination inhibition reaction (5) with 9 and 7 antigens of Influenza virus type A strains with antigen formula H1N1(A/Chile/1/83, A/Taiwan/1/86, A/Singapore/6/86, S.Carolina/6/88, A/Victoria/36/88, A/Texas/36/91, A/Bern/7/96, A/New Caledonia/20/99) and $\mathrm{H}_{3} \mathrm{~N}_{2}$ (A/Mississippi/1/85, A/Sankt-Peterburg/360/86, A/Shanghai/11/87, A/Johannesburg/33/94, A/Wuhan/359/95, A/Sidney/5/97, A/Moskow/10/99, A/Panama2007/99) respectively.

Address for correspondence:

V. Russev, Dept. of Microbiology\&Virology

55 Marin Drinov Str.; 9002 Varna, Bulgaria

e-mail: v_russev@abv.bg

\section{RESULTS AND DISCUSSION}

The dynamic of mean geometrical titers of antihaemaglutinine Abs, directed to reference Influenza virus type $\mathrm{A}(\mathrm{H} 1 \mathrm{~N} 1)$ strains are shown on fig. 1. We proved that titers varied between 2 (A/Taiwan/1/86) - 1999 to 20 (A/New Caledonia/20/99) - 2003.

The geometrical titers of antihaemaglutinine Abs against reference Influenza virus type $\mathrm{A}\left(\mathrm{H}_{3} \mathrm{~N}_{2}\right)$ strains are shown on fig. 2. They vary between 2 (A/Johannesburg/33/94, A/Wuhan/359/95) - 2000-2001 to 10 (A/Sankt-Peterburg /360/86) - 1992-1995 and Moscow 10/99 - 2003-2004.

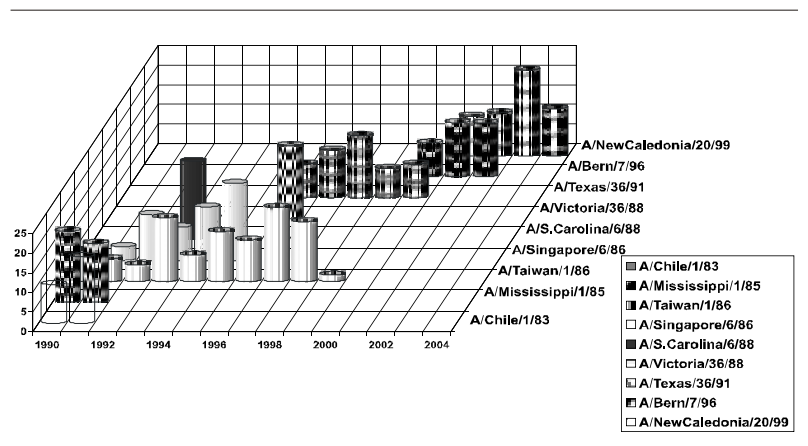

Fig. 1.The dynamic of mean geometrical titers of antihaemaglutinine Abs, directed to reference Influenza virus type $A\left(H_{1} N_{1}\right)$ strains

\section{CONCLUSIONS}

$\mathrm{Ab}$ titers after epidemic usually don $\mathrm{t}$ reach high values and comparatively quickly decrease during the next year. These results in some cases reflect the epidemiological situation - viruses type $\mathrm{A}\left(\mathrm{H}_{3} \mathrm{~N}_{2}\right)$, and in other cases they have 
to be interpreted as a result of anamnestic reactions to former strains, under the influence of diseases, caused by newer strains (H1N1). The serologic indices of the collec-

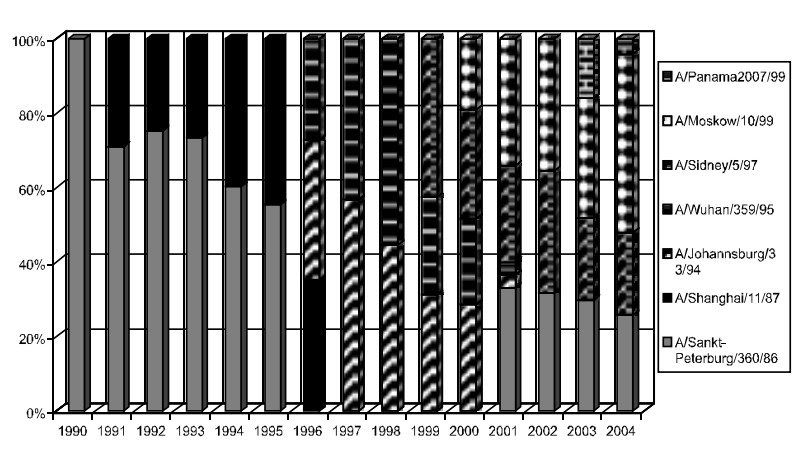

Fig. 2. The geometrical titers of antihaemaglutinine Abs against reference Influenza virus type $\mathrm{A}\left(\mathrm{H}_{3} \mathrm{~N}_{2}\right)$ strains

tive antiinfluenza immunity of the population are higher for Influenza Virus type A (N1N1) (0-20) in contrast for type A (H3N2) (0-10). This is probably a result of the limited circulation of the later virus.

\section{REFERENCES}

1. Fedorova GI. Slepushkin AN. Popova NS. Mel'nichenko El. Markina IA. Correlations of the antigenic specificity of human blood with the levels of antihemagglutinins to influenza viruses. Vopr. Virusol. 1983 Jan-Feb;28(1):54-7.

2. Ismagulov AT. Utegulova AG. Antonenko ZP. Shavrina IA. Epidemiological surveillance of influenza based on research data on collective immu- nity. Zh. Mikrobiol. Epidemiol. Immunobiol. 1986 Nov; 1 (1):34-6.

3. Naikhin AN. Denisov GM. Ivannikov luG, Lisok TP. Oleinikova EV. Results of a study of collective immunity to influe A virus (H1N1) from 1976 to 1980. Vopr. Virusol. 1981 Sep-0ct;(5): 553-7.

4. Naikhin AN. Katorgina LG. Tsaritsyna IM. Kirn TN. Reznik VN. Trusov NV. Denisov GM. Indicators of collective immunity to influenza depending on the blood group and sex of the population. Vopr. Virusol. 1989 Jul-Aug;34(4):419-23.

5. Nicholson K. G., R. G. Webster, A.J. Hay, Textbook of influenza, 1998, Blackwell Science,United Kingdom.

6. Shvartsman laS. Agranovskaia EN. Grigoreva SK. Maltseva AI. Koval TA.Participation of secretory antibodies in the protecti from influenza. Zh Mikrobiol Epidemiol Immunobiol. 1977 Sep;(9):53-6.

7. Skripchenko GS, Poliakov EM, Kniazeva NL.Immunological precursors of influenza epidemics. Zh Mikrobiol Epidemiol Immunobiol. 1978 May;(5):70-7.

8. Skripchenko GS. Poliakov EM.L Kniazeva NI. Immunological precursors of influenza epidemics Zh Mikrobiol Epidemiol Immunobiol. 1978 May;(5):70-7.

9. Slepushkin AN. Fedorova GI. Popova NS. Melnichenko E1. Anti-influenza immunity and the prediction of influenza morbidity in the upcoming epidemic seas Vopr. Virusol. 1983 May-Jun; (3): 290-2.

10. Taros LIu. Zhilova GP. Smorodintsev, Related Articles, L A A. Changes in the indices of the immunogenic activity influenza A/Hong Kong virus in the 1969-1980 epidemics. Vopr. Virusol. 1981 Nov-Dec;(6): 664-7. 